ANNALS OF

APPLIED BIOLOGY

\title{
New insights on Flavescence dorée phytoplasma ecology in the vineyard agro-ecosystem in southern Switzerland
}

\begin{tabular}{|c|c|}
\hline Journal: & Annals of Applied Biology \\
\hline Manuscript ID & AAB-2016-0324.R2 \\
\hline Manuscript Type: & Research paper \\
\hline Date Submitted by the Author: & $\mathrm{n} / \mathrm{a}$ \\
\hline Complete List of Authors: & $\begin{array}{l}\text { Casati, Paola; Università degli Studi di Milano, Dipartimento di Scienze } \\
\text { Agrarie e Ambientali - Produzione, Territorio, Agroenergia (DiSAA) } \\
\text { Jermini, Mauro; Dipartimento federale dell'economia, della formazione e } \\
\text { della ricerca (DEFR) - Agroscope, Istituto delle scienze della produzione } \\
\text { vegetale (IPV), Centro di Cadenazzo } \\
\text { Quaglino, Fabio; Università degli Studi di Milano, Dipartimento di Scienze } \\
\text { Agrarie e Ambientali - Produzione, Territorio, Agroenergia (DiSAA) } \\
\text { Corbani, Giacomo; Università degli Studi di Milano, Dipartimento di Scienze } \\
\text { Agrarie e Ambientali - Produzione, Territorio, Agroenergia (DiSAA) } \\
\text { Schaerer, Santiago; Département fédéral de I'économie, de la formation et } \\
\text { de la recherche (DEFR) - Agroscope, Département Protection des végétaux } \\
\text { grandes cultures et vigne/Viticulture et oenologie } \\
\text { Passera, Alessandro; Università degli Studi di Milano, Dipartimento di } \\
\text { Scienze Agrarie e Ambientali - Produzione, Territorio, Agroenergia (DiSAA) } \\
\text { Bianco, Piero; Università degli Studi, Dipartimento di Scienze Agrarie e } \\
\text { Ambientali - Produzione, Territorio, Agroenergia (DiSAA) } \\
\text { Rigamonti, Ivo; Universita degli Studi di Milano, Dipartimento di Scienze } \\
\text { per gli Alimenti, la Nutrizione, I'Ambiente (DeFENS) }\end{array}$ \\
\hline Key Words: & $\begin{array}{l}\text { Grapevine yellows, Phytoplasma, Insect vectors, }<\mathrm{i}>\text { map }</ \mathrm{i}>\text { gene, } \\
<\mathrm{i}>\text { Orientus ishidae }</ \mathrm{i}>\text {, Hazel, Willow }\end{array}$ \\
\hline
\end{tabular}


1 New insights on Flavescence dorée phytoplasma ecology in the 2 vineyard agro-ecosystem in southern Switzerland

3

4 Casati P. ${ }^{1, \dagger}$, Jermini M. ${ }^{2, \dagger}$, Quaglino F. ${ }^{1}$, Corbani G. ${ }^{1}$, Schaerer S. ${ }^{2}$, Passera A. , 5 Bianco P.A. ${ }^{1}$, Rigamonti I.E. ${ }^{3}$

6

$7 \quad{ }^{1}$ Dipartimento di Scienze Agrarie e Ambientali - Produzione, Territorio, Agroenergia (DiSAA), Università 8 degli Studi di Milano, via Celoria 2, 20133 Milan, Italy

$9 \quad{ }^{2}$ Research Station Agroscope Changins - Wädenswil ACW, Centro di Ricerca di Cadenazzo (TI). A Ramél, 10 18, CH-6593 Cadenazzo, Switzerland

$11{ }^{3}$ Dipartimento di Scienze per gli Alimenti, la Nutrizione, l'Ambiente (DeFENS), Università degli Studi di 12 Milano, Via Celoria 2, 20133 Milan, Italy

13

Running title: Insights on Flavescence dorée ecology

\footnotetext{
${ }^{\dagger}$ The first two authors contributed equally to the work
} 


\section{SUMMARY}

Phytoplasmas associated with Flavescence dorée (FDp) grapevine disease are quarantine pathogens controlled through mandatory measures including the prompt eradication and destruction of diseased plants, and the insecticide treatments against the insect vector, the ampelophagous leafhopper Scaphoideus titanus. In the present study, a multidisciplinary approach has been applied to investigate the FDp ecological cycle in a test vineyard agro-ecosystem in Canton Ticino, south Switzerland. Despite the scarce population density of $S$. titanus, a regular trend of new infections (3.4\% of the total vines) through the years was observed. The leafhopper Orientus ishidae was found as the most abundant among the captured insect species known as phytoplasma vectors (245 out of 315 specimens). The population of $O$. ishidae was evidenced prevalently (167 specimens) in the south-western side of the vineyard and within the neighboring forest constituted mainly by hazel (Corylus avellana) and willow (Salix spp.). These plant species were found infected by FDp related strains (30\% of analyzed trees) for the first time in this study. Interestingly, $O$. ishidae was found to harbor FDp related strains in high percentage ( $26 \%$ of the analyzed pools). In addition, $16 \mathrm{SrV}$ phytoplasma group was detected for the first time in the insect Hyalesthes obsoletus and a FDp related strain in Thamnotettix dilutior, present in low populations within the test vineyard. Molecular characterization and phylogenetic analyses of map gene sequences of FDp and related strains, here identified, revealed the great prevalence of the map-type FD2 in grapevines (97\%) and in $O$. ishidae pools (72\%). Such a map-type was found also in hazel and in T. dilutior, but not in $S$. titanus. Moreover, map-types FD1 and FD3 were identified for the first time in Switzerland in several host plants and phytoplasma vectors, including grapevine (FD1), S. titanus (FD1) and $O$. ishidae (FD1 and FD3). Based on the data obtained in this study, it is reasonable to hypothesize that the ecological cycle of FDp could be related not exclusively to the grapevine-specific feeding diet of S. titanus, but it could include other insect vector(s) and/or plant host(s). Further studies will be 
49

50

51

52

53

54

55

56

57

58

59

60

61

62

63

64

65

66

67

68

needed to prove the role of $O$. ishidae as vector able to transmit FDp from wild plants (e.g. hazel) to grapevine.

Keywords: Grapevine yellows; Phytoplasma; Insect vectors; map gene; Orientus ishidae; Hazel;

Willow

\section{INTRODUCTION}

Flavescence dorée (FD) is the most epidemic disease within the grapevine yellows (GY) complex, and causes strong economic damages to viticulture in Europe, both in terms of quality and quantity (Belli et al., 2010). Typical FD symptoms, indistinguishable from those associated with other diseases of the GY complex, include berry shrivel, desiccation of inflorescences, color alterations and curling of the leaves, reduction of growth, and irregular ripening of wood (Belli et al., 2010).

Based on nucleotide sequence analysis of the gene $16 S$ rRNA and the intergenic spacer between $16 S$ and $23 S$ rRNA genes, FD phytoplasmas (FDp) have been classified in two taxonomic subgroups belonging to the $16 \mathrm{SrV}$ group (Elm yellows group), 16SrV-C and -D (Lee et al., 1998; Angelini et al., 2001; Davis \& Dally, 2001; Lee et al., 2004). As reported for other phytoplasmas belonging to taxonomic group 16SrV (Martini et al., 2002; Navrátil et al., 2009; Malembic-Maher et al., 2011), the variability of the $16 S$ rRNA gene is insufficient to account for the emerging ecological differences in FDp biological cycles. Thus, further studies focus on finer differentiation of phytoplasmas associated with FD. Molecular and phylogenetic analyses on the genetic locus map demonstrate the presence of three map-types: FD1 and FD3 (including strains from subgroup 16SrV-C), and FD2 (including strains from subgroup 16SrV-D) (Arnaud et al., 2007). Geographic distribution of map-types is different: (i) FD1 and FD2 have been identified, respectively, in 17\% and $83 \%$ of symptomatic grapevines in France, where FD3 is not present (Arnaud et al., 2007); (ii) 
74 the three map-types have been identified in Italy, with a prevalence of FD1 and FD3 in north75 western and north-eastern regions, respectively (Arnaud et al., 2007; Foissac \& Maixner, 2013); 76 (iii) FD2 and FD3 have been detected in Slovenia and Croatia, with a prevalence of FD3 (Mehle et 77 al., 2011; Plavec et al., 2015); (iv) only FD3 has been identified in Serbia (Filippin et al., 2009); (v)

Moreover, nucleotide sequences and phylogenetic analyses from multiple genes indicate that FDp, Palatinate grapevine yellows phytoplasmas (PGYp) and Alder yellows phytoplasma (AldYp) are clustered together, supporting their monophyletic origin (Arnaud et al., 2007; Holz et al., 2015). AldYp, widespread in Europe and never detected in America, is transmitted by the insect Oncopsis alni (Schrank) (Maixner \& Reinert, 1999). Such highlights suggest that FDp could have originated in Europe. As a matter of fact, it has been hypothesized that (i) AldYp strains, genetically related to FD1, FD2 and FD3 map-types of FDp, are occasionally transmitted to grapevine by $O$. alni (Maixner et al., 2000); (ii) after the entrance of Scaphoideus titanus Ball in Europe, such AldYp strains have been transmitted exclusively to grapevine, generating the FD epidemics (Arnaud et al., 2007).

Due to the host plant range and feeding preferences of each phytoplasma vector, the majority of GY (e.g. Bois Noir and Palatinate grapevine yellows) spreads only slowly and, apparently, not from vine to vine. On the other hand, FD is an epidemic disease characterized by its rapid spread within vineyards due to vine-to-vine transmission (EPPO/CABI, 1996). FDp are transmitted by $S$. titanus, a monovoltine leafhopper accidentally introduced to France from North America in the 1950ies. In Europe only species of the Vitis genus have been shown to sustain the whole life cycle, from egg to egg, of S. titanus; moreover, this leafhopper is considered as oligophagous (Chuche \& Thiéry, 2014). Consequently, geographic areas hosting large vector populations can be damaged by strong FD epidemics if FDp are also present. Due to this aspect, 
99 phytoplasmas associated with FD are quarantine pathogens to be controlled through mandatory

100 measures: (i) promptly eradicating and destroying any plants showing GY type symptoms, even

101 before confirmation of FD infection by laboratory tests where FD is already present, and (ii)

102 compulsory insecticide sprayings to control the S. titanus populations. The number of applications

103 varies from one to three per year (targeting nymphs and adults) in commercial vineyards and can be

104

105

106

107

108

109

110

111

112

113

114

115

116

117

118

119

120

121

122 more numerous in nurseries (EFSA, 2014). Even though these measures have reduced the impact of FD, the still broad presence of FDp in different countries indicates that FD epidemic is still important (Botti \& Bertaccini, 2007; Jermini et al., 2014).

Moreover, recent studies report that the FD epidemiological cycle could be more complex than the exclusive FDp transmission from grapevine to grapevine by $S$. titanus; in fact, (i) FDp related strains are also commonly found in other plant hosts such as Ailanthus, Alnus, and Clematis (EFSA, 2014); (ii) several studies reveal that S. titanus can feed on other plant species, on which it can only partially complete its biological cycle (Schvester et al., 1962; Caudwell et al., 1970; Trivellone et al., 2013); these host plants could play a role as source of inoculum for FDp transmission to grapevine (Chuche \& Thiery, 2014); (iii) other studies reveal that FDp can be transmitted to grapevine by other insects. In detail, Filippin and colleagues (2009) have demonstrated that FDp can be transmitted from Clematis vitalba L. to grapevine by the planthopper Dictyophara europaea (L.). The frequency of phytoplasma transmission from Clematis to grapevine remains to be determined but phytoplasma transmission cannot provoke an FD outbreak in the absence of the leafhopper $S$. titanus (EFSA, 2014). Recently, the leahoppers O. alni (Maixner et al., 2000; Arnaud et al., 2007; Mehle et al., 2011) and Orientus ishidae (Matsumura) (Mehle et al., 2010, 2011; Gaffuri et al., 2011; Koczor et al., 2013) have been found infected by FDp related strains in Europe; moreover, latest findings revealed the capability of $O$. ishidae to transmit $16 \mathrm{SrV}$ group phytoplasmas to grapevine (Lessio et al., 2016). 
Based on such previously described evidences, in the present study carried out in Canton Ticino (Switzerland), a molecular epidemiology approach has been used to test if the FD complex could be considered as an open system by investigating the presence of putative vectors and host plants in the vineyard agro-ecosystem. A special focus has been laid on $O$. ishidae, previously found harboring FDp related strains in the studied area (Trivellone et al., 2016); for the first time, particular attention was paid to investigate the epidemiological role of $O$. ishidae plant hosts in the vineyard and its surroundings.

\section{MATERIALS AND METHODS}

\section{Characteristics of the test vineyard}

Investigation about the FD epidemiology was carried out in one vineyard, hereby named "the test vineyard", located in Stabio, a town in the Southern wine-growing region of canton Ticino, Switzerland [WGS 84 (lat/lon) 45.85547, 8.92749; Alt $371 \mathrm{~m}$ ] and in the surrounding vegetation. The test vineyard consists of 21 rows (2177 vines) of Chardonnay vines grafted on $3309 \mathrm{C}$ rootstock. In this vineyard, grapevines are trained using the Guyot system (distance between rows 2 $\mathrm{m}$; plant distance along the row $1 \mathrm{~m}$ ), occasionally mowing between the rows and chemical weeding along the rows. The vineyard is bordered by woods to the south, meadows to northwest, and vineyards to the east (Figure 1). Based on the directives established by the Cantonal Phytosanitary Service, mandatory destruction of grapevine plants showing GY-typical symptoms are carried out in the vineyard, as well as insecticide treatments against $S$. titanus with the larvicidal insecticide Buprofezin at two time points, at maximum egg hatching and two weeks later, according to monitoring activities and model predictions (Prevostini et al., 2013). Despite these measures, adopted since 2005, and the absence of abandoned vineyards, FD is still present in this area. In 
147 particular, 3.3\% of the grapevine plants in our test vineyard were FDp-positive in 2013 (data from

148 Research Station Agroscope Changins, Switzerland).

149

150

Insect monitoring and sampling

151

The activities were carried out from May to November 2014 with the aim to (i) monitor the

152

153

154

155

156

157

158

159

160

161

162

163

164

165

166

167

168

169

170

171 presence of $S$. titanus and $O$. ishidae nymphs and adults developing on grapevine and wild plants in the test vineyard and in its surroundings, (ii) survey the leafhopper species known as putative phytoplasma vectors inhabiting the vine plants, (iii) determine the flight dynamics of $S$. titanus and $O$. ishidae by monitoring the presence of their adults spreading/dispersing through/across the test vineyard and in its surroundings.

(i) Three groups each of 30 grapevine plants, randomly selected within the test vineyard, have been sampled weekly from May 13 to September 30 (21 overall samples) with the beating tray method (one hit per plant). Moreover, wild plants hosting known leafhopper phytoplasma vectors, around and within the test vineyard and in neighbouring vineyards, have been occasionally sampled from June 3 to September 2 (38 overall samples) by the beating tray method (up to 4 hits per plant, according to the plant dimension, until reaching 40 hits).

(ii) Fourteen Aeroxon yellows sticky traps $(10 \times 25 \mathrm{~cm})$ placed horizontally in grapevine canopy (Jermini et al., 1992a, 1992b) were used to detect the presence of S. titanus and other Auchenorrhyncha on the canopy inside the vineyard from July 01 to November 04 . Traps were collected and substituted each week.

These two methods also allowed to simultaneously survey other leafhoppers inhabiting grapevine and wild plants in the test vineyard and in its surroundings.

(iii) Rebell yellow sticky traps $(8 \times 16 \mathrm{~cm})$, placed vertically outside the plant canopy, were utilized to capture leafhoppers spreading/dispersing through/across the vineyard and the surrounding vegetation, with the specific objective to determine the flight dynamics of $S$. titanus 
172 and $O$. ishidae. In detail, six Rebell traps (V1 to V6; V, vineyard) were positioned inside the test

173 vineyard (May 13 - November 04), eight (B1 to B8; B, border) on its borders (May 13 - November

174 04), and nine (W1 to W9; W, woods) outside of it (July 30 - November 04). Particularly, traps W1

175 to W7 were positioned at the external border of the forest neighbouring to the test vineyard, close to

176 other vineyards of the examined area; traps W8 and W9 were positioned inside the forest

177 neighbouring to the test vineyard (Figure 1). Traps were collected and substituted each week.

178 Auchenorrhyncha specimens, after being sorted out from the material caught by the traps

179 and the beating tray, were individually identified at the species level with a stereo microscope. All

180 individuals of species belonging to the subfamily Deltocephalinae, considered putative vectors of

181 FDp (Bressan et al., 2006), and other leafhopper and planthopper species, reported in the scientific

182 literature as known vectors of phytoplasmas, were preserved in $70 \%$ alcohol for further molecular 183 analyses.

185 Plant sampling

186 During a survey on GY carried out from July to September 2014 in the test vineyard, 187 symptomatic leaves were sampled from 74 grapevine plants, showing GY symptoms for the first 188 time. Furthermore, leaf samples were also collected from symptomless woody and shrubby plants 189 of species (Betula pendula, Carpinus betulus, Corylus avellana, Salix caprea, Salix sp., Prunus 190 laurocerasus, Urtica dioica) listed in the scientific literature as host plants of $O$. ishidae 191 (https://gd.eppo.int/reporting/article-4763; Günthart et al., 2004; Nickel, 2010; Mehle et al., 2011). 192 Finally, leaves were also collected from symptomless plants reported as hosts of phytoplasmas 193 closely related to FD (Clematis vitalba) (Filippin et al., 2009). Leaf samples from Madagascar 194 periwinkle (Catharanthus roseus L. (G. Don)) plants, maintained in the greenhouse of the 195 Department of Agriculture and Environmental Sciences (University of Milan, Italy), infected by 196 FDp strains FD92 (subgroup 16SrV-D) and FD70 (subgroup 16SrV-C), 'Ca. Phytoplasma solani' 
197 strain STOL (subgroup 16SrXII-A), and 'Ca. Phytoplasma asteris' strain AY1 (subgroup 16SrI-B),

198 were collected and used as controls in molecular analyses.

199

200

Total nucleic acids extraction

201

202

Total nucleic acids were extracted from pools of the captured insects (each pool includes one to five specimens captured together on the same trap) following a protocol adapted from Alma 203 bromide (CTAB); $100 \mathrm{mM}$ Tris $\mathrm{pH} 8.0,1.4 \mathrm{M} \mathrm{NaCl} ; 50$ mM EDTA pH8; $1 \%$ PVP-40; 0.5\% 206 ascorbic acid). After incubation at $65{ }^{\circ} \mathrm{C}$ for 20 min, nucleic acids were extracted with one volume of chloroform:isoamyl alcohol $24: 1 \mathrm{v} / \mathrm{v}$ solution and then precipitated with the addition of one volume of cold isopropanol at $-20^{\circ} \mathrm{C}$ for $20 \mathrm{~min}$. The obtained total nucleic acids pellet was washed with $70 \%$ ethanol, vacuum dried, redissolved in $50 \mu \mathrm{L}$ TE pH 8.0 and maintained at $-20{ }^{\circ} \mathrm{C}$ until further use.

Total nucleic acids were extracted from examined plants using a modified Angelini et al. (2001) protocol. Briefly, leaf petioles (1 g) were inserted in extraction bags $(12$ x $12 \mathrm{~cm})$ (Bioreba, Reinach, Swizterland) and ground in $7 \mathrm{ml}$ of pre-warmed $\left(65^{\circ} \mathrm{C}\right) 2.5 \%$ CTAB-based buffer (see above) using a Tissue Homogenizer (Sediag, Longvic, France). The solution (1 ml) was held at 65 ${ }^{\circ} \mathrm{C}$ for $30 \mathrm{~min}$. After incubation, nucleic acids were extracted by adding chloroform:isoamyl alcohol $24: 1 \mathrm{v} / \mathrm{v}$ solution and precipitated by incubation with isopropanol at $-20{ }^{\circ} \mathrm{C}$ for $10 \mathrm{~min}$. The nucleic acid pellet was washed with $70 \%$ ethanol, dried, resuspended in TE buffer, re-precipitated with sodium acetate and absolute ethanol, and re-purified by washing with $70 \%$ and $80 \%$ ethanol. Obtained nucleic acids pellet was air-dried, suspended in $100 \mu \mathrm{L}$ of deionised autoclaved water and 221 maintained at $-30{ }^{\circ} \mathrm{C}$ until further use. 


\section{Detection of Flavescence dorée phytoplasma and related strains}

223

224

225

226

227

228

229

230

231

232

233

234

235

236

237

238

239

240

241

242

243

244

245

246

Total nucleic acids extracted from each plant sample and insect pool were used as templates for real-time PCR assays carried out for the FDp and related strains-specific amplification of the gene rplN, coding the ribosomal protein L14 (Durante et al., 2012), using the commercial kit Realtime PCR (TaqMan probe and primers) (IPADLAB, Lodi, Italy) and TaqMan Universal PCR master mix (Applied Biosystems, Monza, Italy), according to the manufacturer's instructions. Thermocycling was carried out on the StepOnePlus Real-Time PCR System (Applied Biosystems,) and consisted of an initial denaturation at $95{ }^{\circ} \mathrm{C}$ for $10 \mathrm{~min}$ followed by 40 cycles of $15 \mathrm{sec}$ at $95{ }^{\circ} \mathrm{C}$ and $1 \mathrm{~min}$ at $62{ }^{\circ} \mathrm{C}$. Total nucleic acids extracted from periwinkle plants infected by phytoplasma strains were used as positive (strains FD92 and FD70) and negative (strains AY1 and STOL) controls; moreover, total nucleic acids from healthy periwinkle plants and reaction mixture without template were used as negative controls. Each sample was analyzed in duplicate.

\section{Flavescence dorée phytoplasma and related strain typing}

FDp and related strains, identified in plants and insect pools by real-time PCR assay, were typed by PCR-based amplification and sequence analyses of the gene map encoding a methionine aminopeptidase (Arnaud et al., 2007). Precisely, total nucleic acids of infected plants and insect pools were employed as templates in nested PCR assays performed using primer pair FD9f5/MAPr1 followed by FD9f6/MAPr2, following the reaction conditions previously described (Arnaud et al., 2007). All amplifications were performed using the GeneAmp PCR System 9700 (Applied Biosystem). Positive and negative controls employed in nested PCR amplification of map gene were as described above. PCR products were analysed by electrophoresis in $1 \%$ agarose gels, stained with ethidium bromide and observed under UV light.

As indicated by Arnaud et al. (2007), map gene amplicons were typed by restriction fragment length polymorphism (RFLP) analysis performed through double digestion with the 
enzymes $A l u$ I and Eco72I Fast digest (MBI-Fermentas). Reactions were carried out according to the manufacturer's instructions. RFLP profiles obtained were visualized under UV light in 3\% agarose gels stained with ethidium bromide. Attribution of FDp and related strains, identified in the present study, to the map-types FD1, 2, and 3 was carried out through the comparison of their AluI-Eco72IRFLP profiles with those described in literature (Arnaud et al., 2007).

Map gene fragments amplified from FDp and related strains, representative of the obtained AluI-Eco72I-RFLP profiles and of the phytoplasma hosts, were selected for nucleotide sequence analyses. The map gene amplicons were sequenced in both senses (employing primers FD9f6 and MAPr2) by a commercial service (Eurofins, Milan, Italy) to achieve at least $5 \mathrm{x}$ coverage per base position. Nucleotide sequence data were assembled by employing the Contig Assembling program of the software BioEdit version 7.0.5 (http://www.mbio.ncsu.edu/bioedit/bioedit.html). Map gene nucleotide sequences of FDp and $16 \mathrm{SrV}$ group phytoplasma strains previously published were retrieved from GenBank (Table S1) and utilized for comparison with the sequences obtained in this study. Map gene nucleotide sequences were aligned using the "ClustalW Multiple Alignment" application and analyzed for sequence identity determination using the "Sequence Identity Matrix" application of the software BioEdit.

Nucleotide sequences of map gene of FDp and related strains and $16 \mathrm{SrV}$ group phytoplasma strains from the present study and previously described in GenBank were employed for phylogenetic analyses. Minimum-Evolution method was carried out using the Jukes-Cantor model and bootstrap replicated 1000 times with the software MEGA6 to obtain an unrooted phylogenetic tree (Tamura et al., 2013).

\section{RESULTS}

\section{Insect monitoring}


A total of 315 specimens belonging to seven species, previously reported as known or 273 putative phytoplasma vectors, were captured on Rebell and Aeroxon sticky traps positioned inside, 274 on the borders and outside the test vineyard, and by beating tray method. The captured specimens 275 belonged to two Cixiidae species, Hyalesthes obsoletus Signoret (15) and Reptalus cuspidatus 276 (Fieber) (6), and to five Cicadellidae species, Orientus ishidae (245 specimens), Scaphoideus 277 titanus (45), Thamnotettix dilutior (Kirschbaum) (2), Fieberiella florii (Stål) (1), and Anoplotettix 278 fuscovenosus (Ferrari) (1), all belonging to the Deltocephalinae subfamily (Table 1).

279 Captures obtained by beating tray method and Aeroxon traps evidenced that three insect 280 species (S. titanus, O. ishidae, and H. obsoletus) are present on the grapevine canopy in the test 281 vineyard. In detail, it was possible to observe on grapevine canopy (i) three nymphs (two at May 27 282 and one at July $1^{\text {st }}$ ) and 13 adults (two captured by beating tray in August and 11 by Aeroxon trap in 283 August/September) of S. titanus, evidencing a sporadic presence of the insect throughout the season 284 (Figure 2A); (ii) 22 adults of $O$. ishidae captured by Aeroxon traps, evidencing a sporadic presence 285 of the insect during the summer and a peak of captures in October (Figure 2A); (iii) three adults of 286 H. obsoletus captured in July by Aeroxon traps. Furthermore, from June 21 to July 30, beating tray 287 method allowed the capture of four nymphs of $O$. ishidae from willow (two positive samples out of 288 six), and two nymphs and three adults of $O$. ishidae from hazel tree (three positive samples out of 289 six).

Captures obtained by Rebell traps highlighted that (i) $O$. ishidae adult population was 291 prevalently spread on the borders (111 out of 214) and on the surrounding vegetation (96 out of 292 214); only seven specimens were captured inside the test vineyard; (ii) the same trend was observed 293 for S. titanus (28 specimens out of 29 on the borders and outside the vineyard; only one specimen 294 captured inside the vineyard) (Table 1). Moreover, the obtained results evidenced that specimens of 295 O. ishidae (167 out of 214) and S. titanus (28 out of 29) were mainly captured on four traps located 296 closely together at the south-western limit of the experimental area. Two traps (B3, B4) were on the 
297 borders of the test vineyard (103 O. ishidae and 7 S. titanus), and two (W8, W9) were on the 298 surrounding vegetation, inside the forest where several hazel trees are present (64 O. ishidae and 21 299 S. titanus) (Figure 1, Table 1). Concerning other planthoppers and leafhoppers, R. cuspidatus, $T$. 300 dilutior and the majority (9 out of 15) of H. obsoletus specimens were captured by traps positioned 301 on the vineyard borders. Moreover, unique specimens of F. florii and A. fuscovenosus were 302 captured inside and outside the vineyard, respectively (Figure 1, Table 1).

\section{FDp and related strain identification}

Real-time PCR assays performed to identify FDp and related strains amplified DNA extracted from periwinkle plants infected by FDp strains FD92 and FD70 showed an average Ct (threshold cycle) of 18.05 and 18.88, respectively. No amplification was observed for periwinkle plants infected by phytoplasma strains STOL and AY1, or reaction mixtures without DNA. Only PCR products amplified from insects and plants, with an average $\mathrm{Ct}<37$, were associated with the presence of FDp and related strains. qPCR assays were carried out on total nucleic acids extracted 
322 from 119 plant leaf samples and 146 insect pools. FDp and related strain distribution among tested 323 plants is as follows: 70 out of $74(95 \%)$ grapevine samples, 11 out of $31(35 \%)$ hazel tree samples, 3 324 out of $10(30 \%)$ willow samples, and 3 out of 4 (75\%) Clematis vitalba samples (Table 2).

325 Out of 301 leafhoppers captured by sticky traps, 274 specimens were grouped in 146 pools 326 for further molecular analyses. FDp and related strains were detected in 30 out of 146 insect pools 327 (21\%). In particular, it was identified in 25 out of 97 (26\%) O. ishidae pools, 2 out of 29 (7\%) S. 328 titanus pools, 1 out of $11(9 \%) H$. obsoletus pools and 2 out of 2 (100\%) T. dilutior pools. All 329 examined pools of $F$. florii, $R$. cuspidatus, and A. fuscovenosus were negative (Table 1).

330

331

332

333

\section{FDp and related strain typing}

Nested PCRs carried out using the primer pair FD9f6/MAPr2 amplified DNA from all the plant and insect samples infected by FDp and related strains, with the exception of 5 hazel leaf samples (out of 11) and 2 willow leaf samples (out of 3) (Table 1 and 2). Enzymatic digestions of FD9f6/MAPr2 amplicons with the enzymes AluI and Eco72I produced three restriction profiles among FDp and related strains identified in the present study (Figure 3). The AluI-Eco72I-RFLP patterns obtained in this study were compared to those described in the literature (i.e. FD1, FD2 and FD3; Arnaud et al., 2007). Among the FDp and related strains identified from plants and insects in the test vineyard, the map-type FD2 was prevalent (89 out of 108 , or $82 \%$ ), while map-types FD1 and FD3 were identified in $13(12 \%)$ and $6(6 \%)$ instances, respectively (Table 1 and 2). FD2 was detected in grapevine (68 plants), hazel trees (1 plant), O. ishidae (18 pools) and T. dilutior (2 pools). FD1 was identified in grapevine (2 plants), hazel tree (3 plants), willow (1 plant), O. ishidae (5 pools), and $S$. titanus (2 pools). FD3 was identified in hazel trees (2 plants), C. vitalba (3 plants), O. ishidae (2 pools), and H. obsoletus (1 pool) (Table 1 and 2).

Nucleotide sequence analyses, performed on $22 \mathrm{FDp}$ and related strains and $16 \mathrm{SrV}$ group phytoplasma strains selected on the basis of both their map-type and the phytoplasma hosts (Table 
347 3), confirmed their assignment to map-types as determined by the RFLP assays. As a matter of fact,

348 (i) FDp and related strains with an FD1 RFLP profile shared best map gene sequence identity (99.8

349 to 100\%) with strain FD70, a FD1 reference strain; (ii) FDp and related strains with an FD2 RFLP

350 profile shared best map gene sequence identity (100\%) with strain V00-SP5, a FD2 reference strain;

351 (iii) FDp-related and 16SrV group phytoplasma strains with an FD3 RFLP profile shared best map 352 gene sequence identity (96.9 to $99.6 \%$ ) with strain VI04-Toscana1, a FD3 reference strain (Table 353 S2).

354 Clustering in a phylogenetic tree built using the map gene nucleotide sequences isolated 355 from plant and insect hosts in this study clearly confirms the attribution of the FDp and related 356 strains and 16SrV group phytoplasma strains to map-types FD1, FD2 and FD3 (Figure 4).

357

358

\section{DISCUSSION}

Due to the mandatory application of insecticides, the population of the FDp vector S. titanus within the test vineyard was very low, as shown by the very small number of specimens (three nymphs and two adults) collected by the beating tray method during the growing season and corroborated by the few captures of adults on the Rebell and Aeroxon yellow sticky trap placed inside the test vineyard. This trend confirmed previous evidences by Trivellone et al. (2016), reporting high S. titanus populations in Swiss localities where its control was not mandatory, and low abundances in vineyards treated with insecticides twice during the growing season. Previous works have demonstrated that $S$. titanus can survive and feed on several plants (Trivellone et al., 2013; Chuche \& Thiery, 2014), develop on elm (Gibson, 1973) and lay eggs on elder (Gargani et al., 2013). In the present study, the majority of S. titanus specimens (28 out of 40) was captured on traps B3, B4, W8 and W9 (Figure 1), placed on the borders and outside the test vineyard, close to a wood of mostly hazel and willow trees, with no wild grapevines to be found. Moreover, the two FDp positive $S$. titanus pools, captured on traps W8 and B4, were infected by the map-type FD1 
372 (Table 1). FD1 was never found before in Switzerland neither in vineyards nor in S. titanus, but was

373 the most frequent map-type on hazel and willow trees in the experimental area, and affected a low 374 minority (two out of 70) of FDp-infected grapevine plants in the test vineyard (Table 2). On the 375 other hand, $S$. titanus was not captured by beating tray from hazel and willow trees in the 376 surroundings of the test vineyard. Based on such evidences, it is reasonable to raise the question if 377 S. titanus can live, but not develop, on wild plants long enough to acquire FDp and related strains. 378 Despite the compulsory destruction of grapevines with GY typical symptoms and the 379 insecticide treatments, applied at two distinct time points, 74 symptomatic grapevines (3.4\%) were 380 identified in the test vineyard in 2014 , the same levels as observed in the previous year by 381 Agroscope, suggesting a stable infection rate through the years. This, together with the low 382 populations of $S$. titanus inside and outside the vineyard, as well as the absence of D. europaea and

O. alni [insects known to transmit FDp and related strains from wild plants to grapevine (Chuche \& Thiery, 2014)], points at a scenario, in which FDp could be vectored by other phloem-feeding insects. Interestingly, this study revealed an abundant population of the leafhopper $O$. ishidae, recently found able to transmit $16 \mathrm{SrV}$ phytoplasmas to vines (Lessio et al., 2016). O. ishidae was found to harbor FD related phytoplasma in high percentage (26\% of the examined pools), prevalently at the borders of the test vineyard and within the wood. Our data confirms the $O$. ishidae contamination rates by FDp related strains recently reported for Canton Ticino, Slovenia and Italy (Mehle et al., 2010; Gaffuri et al., 2011; Trivellone et al., 2016) and its presence in vineyards surrounded by woods (Trivellone et al., 2016).

Previous studies report $O$. ishidae as polyphagous, mainly on woody plants (Hamilton, 1985; Nickel, 2010; Mehle et al., 2011; https://gd.eppo.int/reporting/article-4763). Here, as previously reported, nymphs and adults of $O$. ishidae were collected from hazel and willow trees by beating tray method; moreover, the highest density of $O$. ishidae (167 specimens) was observed on traps B3, B4, W8 and W9, which were placed in the southwestern side of the experimental area, at 
397 the border of the test vineyard and within a wood of mostly hazel (Corylus avellana), already 398 known as a plant host for 'Candidatus Phytoplasma asteris' (Cieślińska \& Kowalik, 2011), and 399 willow (Salix spp.) trees, found infected by FDp related strains (30\% of the analyzed samples) for 400 the first time. Moreover, beating tray captures link $O$. ishidae nymphs and adults with hazel and 401 willow, species found infected by FDp related strains in the present study, confirming the role of 402 these plant species as hosts for O. ishidae (Lessio et al., 2016). On the other hand, O. ishidae was 403 not captured by beating tray on Clematis vitalba, a plant rarely found in the examined vineyard and 404 previously reported to host FDp (Filippin et al., 2009). Even more interestingly, even if no $O$. 405 ishidae specimen was captured by beating tray on grapevine plants, 22 specimens were captured 406 inside the vineyard, mainly on horizontal Aeroxon traps, which are known to catch insects living on 407 the vine canopies, suggesting that $O$. ishidae adults could be present on grapevine for extended 408 periods.

412 largely reported as associated with vineyard ecosystems (Bosco et al., 1997; Sanna et al., 2016). 413 Molecular analyses showed that (i) H. obsoletus hosts a 16SrV group phytoplasma strain (Ho1), 414 characterized by the typical RFLP profile of the map-type FD3, but very divergent from FDp and 415 related strains of map-type FD3 based on sequence identity (from 96.9 to $97.3 \%$ ); in fact, map gene 416 nucleotide sequence of strain Ho1 has 15 SNPs compared to the most closely related strain (FDp 417 strain FG1) in FD3 cluster (data not shown); due to the high polyphagy of $H$. obsoletus, it is 418 reasonable to hypothesize that $16 \mathrm{SrV}$ group phytoplasma strain $\mathrm{Ho} 1$ was acquired by occasional 419 feeding of the insect on infected source plant(s), which should be identified in further studies; (ii) $T$. 420 dilutior specimens host FDp related strains indistinguishable from map-type FD2 phytoplasma 421 strains (sequence identity 100\%) identified in grapevine, hazel, and $O$. ishidae in the test vineyard 
422 (Figure 4, Table S2). These evidences, along with the occurrence of a low population in the test

423 vineyard, suggest that $T$. dilutior, if confirmed as vector, could play a marginal role in FDp 424 transmission to grapevine.

425 Together with ongoing field surveys and molecular analyses, the data of the present study, 426 based on the detection of FDp and related strains in multiple plants and insects inside and outside 427 the test vineyard, (i) confirm the presence in vineyard agro-ecosystems of different leafhopper and 428 plant species infected with FDp and related strains, (ii) confirm the high FDp related strains429 infection rate in $O$. ishidae observed in some European Countries (Mehle et al., 2010, 2011; Gaffuri 430 et al., 2011; Koczor et al., 2013; Trivellone et al., 2016), and (iii) show for the first time the high 431 FDp related strain infection rate in hazel, a host plant of $O$. ishidae (Nickel et al., 2010; Lessio et 432 al., 2016), very common and abundant in Swiss vineyard agro-ecosystems. It is therefore 433 reasonable to hypothesize that the ecological cycle of FDp may be related not exclusively to the 434 grapevine-specific feeding diet of $S$. titanus, but also to that of other insect vector(s) and/or plant 435 host(s). Bressan et al. (2006) tested the specificity of vector transmission of FDp on 15 436 Auchenorrhyncha species, collected in vineyard agro-ecosystem but not developing on grapevine, 437 by abdominal injection of FDp. They demonstrated that three leafhopper species, all belonging to 438 the subfamily Deltocephalinae, transmit FDp. These data suggest that the vector competency of 439 FDp transmission could be widespread and opens the question if in a viticultural area the 440 range/number of effective insect vector species could be determined by the availability of suitable 441 host plant species in a system where FDp strains flow among many different hosts, inside and 442 outside the vineyards.

443 During the last decades, the Asian Cicadellidae $O$. ishidae has been reported from several 444 European Countries. This species has also been introduced in North America during the last 445 century. $O$. ishidae is a sap-feeder; although some damage (i.e. uniform browning of apple and 446 hazel foliage) has occasionally been reported in the USA, it is not considered to be a major pest of 
447 cultivated plants. The main concern raised by the introduction of $O$. ishidae in Europe is the 448 possible transmission of phytoplasma diseases (EPPO, 2015). In fact, experiments conducted in the 449 USA have shown that $O$. ishidae can transmit 'Candidatus Phytoplasma pruni' to celery plants 450 (Rosenberg et al., 1978). Moreover, the present work and recent studies conducted in several 451 European Countries detected the presence of FDp related strains in specimens of $O$. ishidae 452 collected from diseased vineyards (EPPO, 2015). Interestingly, latest findings revealed the 453 capability of $O$. ishidae to transmit $16 \mathrm{SrV}$ phytoplasmas to grapevine (Lessio et al., 2016).

454 In this framework, based on the results obtained in the present study, it is reasonable to 455 assume that the settlement of $O$. ishidae in Canton Ticino at the beginning of the $21^{\text {st }}$ century could 456 have contributed to the persistence of FDp, despite the application of mandatory insecticide 457 treatments, by transmitting FDp from hazel and willow to grapevine, in a way similar to that 458 hypothesized for O. alni (Arnaud et al., 2007; Durante et al., 2012).

459 In the last years, the molecular characterization of phytoplasma species showed molecular 460 diversity, representing ecologically separated populations. The investigation of the genetic diversity 461 among phytoplasmas associated with several diseases allows the identification of strain-specific 462 molecular markers, which are useful to improve the understanding of complex phytoplasma 463 ecologies (Davis et al., 2013; Quaglino et al., 2013). Indeed, among grapevine yellows, the 464 knowledge of the biological complexity of the Bois noir disease was improved through the 465 application of a molecular epidemiology approach (Kostadinovska et al., 2014; Kosovac et al., 466 2016; Murolo \& Romanazzi, 2015; Quaglino et al., 2016). Concerning FD, molecular markers were 467 produced to distinguish FDp strains in different ecological niches (Martini et al., 2002; Botti \& 468 Bertaccini, 2007; Filippin et al., 2009; Quaglino et al., 2010; Malembic-Maher et al., 2011; Durante 469 et al., 2012). The most promising candidate for typing closely related strains within the taxonomic 470 group $16 \mathrm{SrV}$ is the map gene. It distinguishes three map-types (FD1, FD2 and FD3), which are 471 associated with distinct geographic areas (Arnaud et al., 2007) and alder yellows strains in Germany 
472 (Holz et al., 2015). In this study, data from the molecular characterization and phylogenetic 473 analyses of FDp and related strains reveal the great prevalence of the map-type FD2 in grapevines 474 (97\%) and in O. ishidae pools (72\%); FD2 was found also in hazel and in T. dilutior, but not in $S$. 475 titanus. The map-type FD1, identified in few grapevines (3\%), was found also in O. ishidae, S. 476 titanus, C. avellana, and Salix spp.. The map-type FD3, not found in grapevine, was identified in $O$. 477 ishidae, C. avellana, and C. vitalba. Together, these data show that in the test vineyard FD is 478 associated prevalently with phytoplasma strains of map-type FD2.

479 Based on the data obtained in this and in a previous study (Lessio et al., 2016), it is 480 reasonable to hypothesize that in the test vineyard the ecology of FDp is related to grapevine481 specific cycle of $S$. titanus, the cycle of other polyphagous vectors (e.g. O. ishidae), and the 482 presence of other host plants of FDp and related strains (e.g. hazel and willow). Further studies will 483 be needed to prove the role of $O$. ishidae in FD epidemiology. Considering the new scenario 484 describing the FD ecology as an open system, in which the landscape composition can influence the 485 presence of FDp vectors and host plants impacting on FD epidemics, it appears suitable to re486 evaluate the disease control strategies.

487

488 ACKNOWLEDGEMENTS

489 We gratefully thank Prof. Alberto Alma (University of Turin) for sharing important information on 490 O. ishidae obtained in his own researches, and Dr. Valeria Trivellone (Research Station Agroscope 491 Changins, Cadenazzo, Switzerland) for the technical assistance in insect identification. Moreover, 492 we are grateful to Mister Piercarlo Saglini, the owner of the test vineyard.

493

494

\section{REFERENCES}


495 1. Alma A., Bosco D., Danielli A., Bertaccini A., Vibio M., Arzone A. (1997) Identification of 496 phytoplasmas in eggs, nymphs and adults of Scaphoideus titanus Ball reared on healthy $497 \quad$ plants. Insect Molecular Biology, 6, 115-121.

498 2. Angelini E., Clair D., Borgo M., Bertaccini A., Boudon-Padieu E. (2001) Flavescence 499 dorée in France and Italy. Occurence of closely related phytoplasma isolates and their near 500 relationships to Palatinate Grapevine yellows and an Alder yellows phytoplasma. Vitis, 40, $501 \quad 79-86$.

502 3. Anonymous (2015) Orientus ishidae: a potential phytoplasma vector spreading in the EPPO 503 region. EPPO Reporting Service, 5, article 2015/098.

504 4. Arnaud G., Malembic-Maher S., Salar P., Bonnet P., Maixner M., Marcone C., Boudon505 Padieu E., Foissac X. (2007) Multilocus sequence typing confirms the close genetic inter506 relatedness between three distinct flavescence dorée phytoplasma strain clusters and group $507 \quad 16 \mathrm{SrV}$ phytoplasmas infecting grapevine and alder in Europe. Applied and Environmental $508 \quad$ Microbiology, 73, 4001-4010.

509 5. Belli G., Bianco P.A., Conti M. (2010) Grapevine yellows: past, present and future. Journal $510 \quad$ of Plant Pathology, 92, 303-326.

511 6. Bosco D., Alma A., Arzone A. (1997) Studies on population dynamics and spatial 512 distribution of leafhoppers in vineyards (Homoptera:Cicadellidae). Annals of Applied $513 \quad$ Biology, 130, 1-11.

514 7. Botti S., Bertaccini A. (2007) Grapevine yellows in Northern Italy: molecular identification 515 of Flavescence doree phytoplasma strains and of Bois Noir phytoplasmas. Journal of $516 \quad$ Applied Microbiology, 103, 2325-2330.

517 8. Bressan A., Clair D., Sémétey O., Boudon-Padieu E. (2006) Insect injection and artificial 518 feeding bioassays to test the vector specificity of Flavescence dorée phytoplasma. $519 \quad$ Phytopathology, 96, 790-796. 
520 9. Caudwell A., Gianotti J., Kuszala C., Larrue J. (1971) Etude du rôle de particules de type 521 mycoplasme dans l'étiologie de la Flavescence dorée de la vigne. Examen cytologique des

522

523

524

525

526

527

528

529

530

531

532

533

534

535

536

537

538

539

540

541

542

543

544 plants malades et des cicadelles infectieuses. Annales de Phytopatologie, 3, 107-203.

10. Caudwell A., Kuszala C., Bachelier J.C., Larrue J. (1970) Transmission de la Flavescence dorée de la vigne aux plantes herbacées par l'allongement du temps d'utilisation de la cicadelle Scaphoideus littoralis Ball et l'étude de sa survie sur un grand nombre d'espèces végétales. Annales de Phytopatologie, 2, 415-428.

11. Chuche C., Thiery D. (2014) Biology and ecology of the Flavescence dorée vector Scaphoideus titanus: a review. Agronomy for Sustainable Development, 34, 381-403.

12. Cieślińska M., Kowalik B. (2011) Detection and molecular characterization of 'Candidatus Phytoplasma asteris' in European hazel (Corylus avellana) in Poland. Journal of Phytopathology, 159, 585-588.

13. Davis R.E., Dally E.L. (2001) Revised subgroup classification of group $16 \mathrm{SrV}$ phytoplasmas and placement of flavescence dorée-associated phytoplasmas in two distinct subgroups. Plant Disease, 85, 790-797.

14. Davis R.E., Zhao Y., Dally E., Lee I.-M., Jomantiene R., Douglas S.M. (2013) 'Candidatus Phytoplasma pruni', a novel taxon associated with X-disease of stone fruits, Prunus spp.: multilocus characterization based on 16S rRNA, secY, and ribosomal protein genes. International Journal of Systematic and Evolutionary Microbiology, 63, 766-776.

15. Durante G., Casati P., Clair D., Quaglino F., Bulgari D., Boudon-Padieu E., Bianco P.A. (2012) Sequence analyses of S10-spc operon among $16 \mathrm{SrV}$ group phytoplasmas: phylogenetic relationships and identification of discriminating single nucleotide polymorphisms. Annals of Applied Biology, 161, 234-246.

16. European and Mediterranean Plant Protection Organization/Commonwealth Agricultural Bureau International. (1996) Grapevine flavescence dorée phytoplasma. In I.M. Smith, 
545 McNamara D.G., Scott P.R., Holderness M. (ed.), Quarantine pests for Europe, $2^{\text {nd }}$ edition. 546 Commonwealth Agricultural Bureau International, Wallingford, United Kingdom, pp. 1013$547 \quad 1021$.

548 17. European and Mediterranean Plant Protection Organization (2015) Orientus ishidae: a 549 potential phytoplasma vector spreading in the EPPO region. In EPPO Reporting Service 2015 no. 5 - Pest \& Diseases, 2015/98, 8-10.

551 18. European Food Safety Authority (2014). Scientific Opinion on pest categorisation of 552 Grapevine Flavescence dorée. EFSA Panel on Plant Health (PLH). EFSA Journal, 12, 3851. 553 19. Filippin L., Jović J., Cvrković D., Forte V., Clair D., Toševski I., Boudon-Padieu E., Borgo 554 M., Angelini E. (2009) Molecular characteristics of phytoplasmas associated with 555 Flavescence dorée in clematis and grapevine and preliminary results on the role of 556 Dictyophara europaea as a vector. Plant Pathology, 58, 826-837.

557 20. Foissac X., Maixner M. (2013) Spread of grapevine phytoplasma diseases. In Torres E., 558 Laviña A., Jarausch W., Bertaccini A. (ed.), New perspectives in phytoplasma disease 559 management, Book of Abstracts of COST Action FA0807 Workshop; March 22, 2013, $560 \quad$ Barcelona, Spain.

561 21. Gaffuri F., Sacchi S., Cavagna B. (2011) First detection of the mosaic leafhopper, Orientus 562 ishidae, in northern Italian vineyards infected by the flavescence doree phytoplasma. New 563 Disease Reports, 24, 22.

564 22. Gargani E., Torrini G., Caradonna S., Bagnoli B. (2013) Scaphoideus titanus and Metcalfa 565 pruinosa egg distribution on different woody parts of Kober 5BB grapevine. IOBC/wprs $566 \quad$ Bulletin, 85, 37-42.

567 23. Gibson L.P. (1973) An annotated list of the Cicadellidae and Fulgoridae of elm. USDA $568 \quad$ Forest Service Research Paper, NE-278, 1-5. 
569 24. Günthart H., Mühlethaler R., Lauterer P. (2004) Für die Schweiz neue Zikadenarten und 570 Ergänzungen zu bereits bekannten Arten (Hemiptera Auchenorrhyncha). Mitteilungen der 571 Entomologischen Gesellschaft Basel, 54, 150-160.

572 25. Hamilton K.G.A. (1985) Leafhoppers of ornamental and fruit trees in Canada. Agriculture 573 Canada Publication, 1779E/F, 1-71.

574 26. Holz S., Duduk B., Buttner C., Kube M. (2016) Genetic variability of Alder yellows 575 phytoplasma in Alnus glutinosa in its natural Spreewald habitat. Forest Pathology, 46, 1157621.

577 27. Jermini M., D'Adda G., Baumgärtner J., Lozzia G.C., Baillod M. (1992a) Nombre des 578 pièges englués necessaires pour estimer la densité relative des populations de la cicadelle 579 Scaphoideus titanus Ball en vignobles. Bollettino di Zoologia Agraria e Bachicoltura, 25, $580 \quad 91-102$.

581 28. Jermini M., Rossi A., Baillod M. (1992b) Etude du piégeage de la cicadelle Scaphoideus 582 titanus Ball à l'aide de pièges jaunes. Revue Suisse de Viticulture, Arboriculture, $583 \quad$ Horticulture, 24, 235-239.

584 29. Jermini M., Schaerer S., Johnston H., Colombi L., Marazzi C. (2014) Dix ans de 585 flavescence dorée au Tessin. Revue Suisse de Viticulture, Arboriculture, Horticulture, 46, $586 \quad 222-229$.

587 30. Koczor S., Bagarus A.K., Karap A.K., Varga Á., Orosz A. (2013) A rapidly spreading 588 potential pest, Orientus ishidae identified in Hungary. Bulletin of Insectology, 66, 221-224. 589 31. Kosovac A., Radonjić S., Hrnčić S., Krstić O., Toševski I., Jović J. (2016) Molecular tracing 590 of the transmission routes of bois noir in Mediterranean vineyards of Montenegro and 591 experimental evidence for the epidemiological role of Vitex agnus-castus (Lamiaceae) and 592 associated Hyalesthes obsoletus (Cixiidae). Plant Pathology, 65, 285-298. 
593 32. Kostadinovska E., Quaglino F., Mitrev S., Casati P., Bulgari D., Bianco P.A. (2014) $594 \quad$ Multiple gene analyses identify distinct "bois noir" phytoplasma genotypes in the Republic $595 \quad$ of Macedonia. Phytopathologia Mediterranea, 53, 491-501.

596 33. Lee I.-M., Gundersen D.E., Davis R.E., Bartoszik I.M. (1998) Revised classification scheme 597 of phytoplasmas based on RFLP analyses of 16S rRNA and ribosomal protein gene $598 \quad$ sequences. International Journal of Bacteriology, 48, 1153-1169.

599 34. Lee I.-M., Martini M., Marcone C., Zhu S.F. (2004). Classification of phytoplasma strains 600 in the elm yellows group (16SrV) and proposal of 'Candidatus Phytoplasma ulmi' for the 601 phytoplasma associated with elm yellows. International Journal of Systematic and $602 \quad$ Evolutionary Microbiology, 54, 337-347.

603 35. Lessio F., Picciau L., Gonella E., Mandrioli M., Tota F., Alma A. (2016) The mosaic 604 leafhopper Orientus ishidae: host plants, spatial distribution, infectivity, and transmission of $60516 \mathrm{SrV}$ phytoplasmas to vines. Bulletin of Insectology, 69, 277-289.

606 36. Linder C., Cavadini M., Schaerer S. (2014) Dictyophara europaea: un vecteur potentiel de 607 la flavescence dorée en Suisse? Revue Suisse de Viticulture, Arboriculture, Horticulture, 46, $608 \quad 216-219$.

609 37. Maixner M., Reinert W. (1999) Oncopsis alni (Schrank) (Auchenorrhyncha:Cicadellidae) as 610 a vector of the alder yellows phytoplasma of Alnus glutinosa (L.) Gaertn. European Journal 611 of Plant Pathology, 105, 87-94.

612 38. Maixner M., Reinert W., Darimont H. (2000) Transmission of grapevine yellows by 613 Oncopsis alni (Schrank) (Auchenorrhyncha: Macropsinae). Vitis, 39, 83-84.

614 39. Malembic-Maher S., Salar P., Filippin L., Carle P., Angelini E., Foissac X. (2011) Genetic 615 diversity of European phytoplasmas of the $16 \mathrm{SrV}$ taxonomic group and proposal of 616 'Candidatus Phytoplasma rubi'. International Journal of Systematic and Evolutionary $617 \quad$ Microbiology, 61, 2129-2134. 


\begin{abstract}
618 40. Martini M., Botti S., Marcone C., Marzachì C., Casati P., Bianco P.A., Benedetti R., 619 Bertaccini A. (2002) Genetic variability among flavescence dorée from different origins in 620 Italy and France. Molecular and Cellular Probes, 16, 197-208.

621 41. Mehle N., Ravnikar M., Seljak G., Knapiè V., Dermastia M. (2011) The most widespread 622 phytoplasmas, vectors and measures for disease control in Slovenia. Phytopathogenic $623 \quad$ Mollicutes, 1, 65-76.

624 42. Mehle N., Rupar M., Seljak G., Ravnikar M., Dermastia M. (2011) Molecular diversity of 625 'flavescence dorée' phytoplasma strains in Slovenia. Bulletin of Insectology, 64, S29- S30.

626 43. Mehle N., Seljak G., Rupar M., Ravnikar M., Dermastia M. (2010) The first detection of a 627 phytoplasma from the $16 \mathrm{SrV}$ (Elm yellows) group in the mosaic leafhopper Orientus 628 ishidae. New Disease Reports, 22, 11.
\end{abstract}

629 44. Murolo S., Romanazzi G. (2015) In-vineyard population structure of 'Candidatus 630 Phytoplasma solani' using multilocus sequence typing analysis. Infection, Genetics and $631 \quad$ Evolution, 31, 221-230.

632 45. Navrátil M., Šafářová D., Válová P., Fránová J., Šimková M. (2009) Phytoplasma associated 633 with witches'-broom disease of Ulmus minor MILL. in the Czech Republic: electron 634 microscopy and molecular characterization. Folia Microbiologica, 54, 37-42.

635 46. Nickel H. (2010) First addendum to the Leafhoppers and Planthoppers of Germany 636 (Hemiptera: Auchenorrhyncha). Cicadina, 11, 107-122.

637 47. Plavec J., Križanac I., Budinšćak Ž., Škorić D., Šeruga Musić M. (2015) A case study of FD 638 and BN phytoplasma variability in Croatia: multigene sequence analysis approach. 639 European Journal of Plant Pathology, 142, 591-601.

640 48. Prevostini M., Taddeo A.V., Balac K., Rigamonti I., Baumgärtner J., Jermini M. (2013) 641 WAMS - an adaptive system for knowledge acquisition and decision support: the case of 642 Scaphoideus titanus. IOBC-WPRS Bulletin, 85, 57-64. 
643

644

645

646

647

648

649

650

651

652

653

654

655

656

657

658

659

660

661

662

663

664

665

49. Quaglino F., Casati P., Bianco P.A. (2010) Distinct rpsC single nucleotide polymorphism lineages of Flavescence dorée subgroup 16SrV-D phytoplasma co-infect Vitis vinifera L.. Folia Microbiologica, 55, 251-257.

50. Quaglino F., Maghradze D., Casati P., Chkhaidze N., Lobjanidze M., Ravasio A., Passera A., Venturini G., Failla O., Bianco P.A. (2016) Identification and characterization of new 'Candidatus Phytoplasma solani' strains associated with bois noir disease in Vitis vinifera L. cultivars showing a range of symptoms severity in Georgia, the Caucasus region. Plant Disease, 100, 904-915.

51. Quaglino F., Zhao Y., Casati P., Bulgari D., Bianco P.A., Wei W., Davis R.E. (2013) 'Candidatus Phytoplasma solani', a novel taxon associated with stolbur and bois noir related diseases of plants. International Journal of Systematic and Evolutionary Microbiology, 63, 2879-2894.

52. Rosenberger D.A., Jones A.L. (1978) Leafhopper vectors of the Peach X disease pathogen and its seasonal transmission from chokecherry. Phytopathology, 68, 782-790.

53. Sanna F., Quaglino F., Filisetti S., Casati P., Faccincani M., Bianco P.A., Mori N. (2016) Preliminary results on putative vectors of 'Candidatus Phytoplasma solani' in Bois noiraffected vineyards in Franciacorta (Lombardy region, North Italy). Mitteilungen Klosterneuburg, 66, 28-31.

54. Schvester D., Carle P., Moutos G., Bonfils J. (1962) Etudes biologique des cicadelles de la vigne dans le sud-ouest de la France. Annales des épiphyties, 13, 205-237.

55. Tamura K., Stecher G., Peterson D., Filipski A., Kumar S. (2013) MEGA6: Molecular Evolutionary Genetics Analysis Version 6.0. Molecular Biology and Evolution, 30, 2725-2729. 


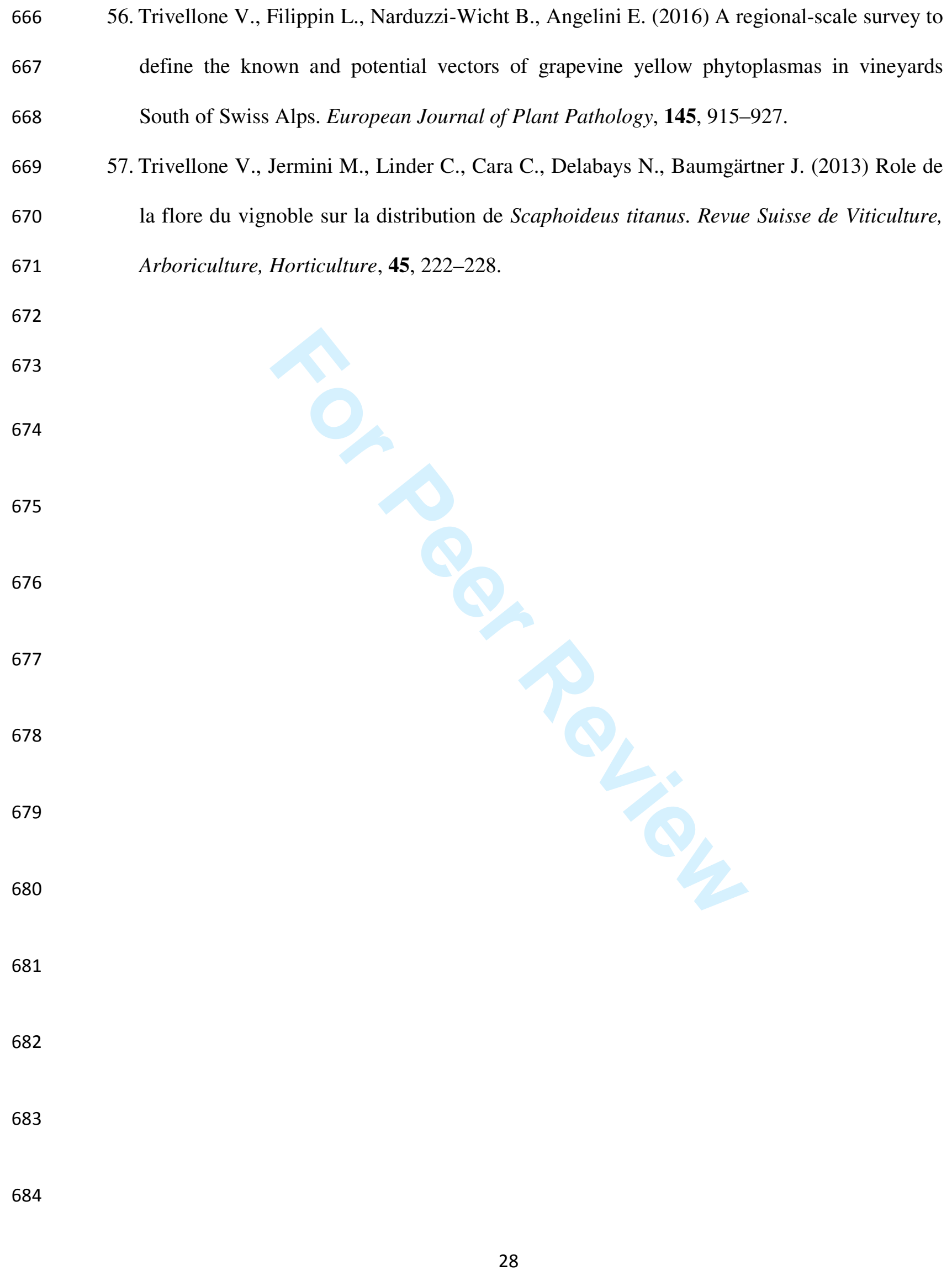




\title{
Supporting Information
}

\author{
Casati et al. [Insights on Flavescence dorée ecology]
}

687

688 Table S1 Map gene nucleotide sequences of 16SrV group strains retrieved from NCBI GenBank

689 for sequence identity and phylogenetic analyses

\begin{tabular}{|c|c|c|c|c|}
\hline Strain & map type & Host & Location & Accession number \\
\hline FD V00-SP5 and V00-SP9 & FD2 & Vitis vinifera & Gironde, France & AM384886 \\
\hline FD V02-101 and V01-9 & FD1 & Vitis vinifera & Gironde, France & AM384887 \\
\hline FD V03-9-2, 9-16, and 9-17 & FD1 & Vitis vinifera & Pyrénés Atlantiques, France & AM384888 \\
\hline FD V04-11-19, 11-21, and 11-53 & FD1 & Vitis vinifera & Lot, France & AM384889 \\
\hline FD VI04-C28 and C29 & FD3 & Vitis vinifera & Veneto, Italy & AM384894 \\
\hline FD VI04-Toscana1 & FD3 & Vitis vinifera & Toscana, Italy & AM384895 \\
\hline FD VI04-188-04 and 248-04 & FD3 & Vitis vinifera & Piemonte, Italy & AM384896 \\
\hline FD FD 70 & FD3 & Catharanthus roseus & France & AM238512 \\
\hline PGY PGY-A & & Vitis vinifera & Rheinland-Pfaltz, Germany & AM384892 \\
\hline PGY PGY-B Yellows (B type) & & Vitis vinifera & Rheinland-Pfalz, Germany & AM384893 \\
\hline PGY PGY-C EY 38 & & Vitis vinifera & Rheinland-Pfalz, Germany & AM384891 \\
\hline PGY V04-11-01 & & Vitis vinifera & Haut-Rhin, France & AM384890 \\
\hline EY1 E04-D714 & & Ulmus glabra & Haute-Vienne, France & AM384901 \\
\hline AldY AI04-3-13 and AI04-3-7 & & Alnus glutinosa & Basilicata, Italy & AM384884 \\
\hline Ald YWJ1444-32 & & Alnus glutinosa & Pyrénés Orientales, France & AM384897 \\
\hline AldY ALY & & Catharanthus roseus & Basilicata, Italy & AM384885 \\
\hline AldY A06-30-3 & FD1 & Alnus glutinosa & Gironde, France & FN561864 \\
\hline AldY Ag30 MAC & & Alnus glutinosa & Macedonia & KJ605451 \\
\hline AldY 74-08-MNE & & Alnus glutinosa & Montenegro & KC188998 \\
\hline AldY SW7 & & Alnus glutinosa & Germany & KP238304 \\
\hline AldY SW38 & & Alnus glutinosa & Germany & KP238315 \\
\hline AldY SW1 & & Alnus glutinosa & Germany & KP238302 \\
\hline AldY 75-08-MNE & & Alnus glutinosa & Montenegro & KC188999 \\
\hline AldY Ag26 MAC & & Alnus glutinosa & Macedonia & KJ605448 \\
\hline AldY Ag27 MAC & & Alnus glutinosa & Macedonia & KJ605449 \\
\hline AldY Ag29 MAC & & Alnus glutinosa & Macedonia & KJ605450 \\
\hline AldY A06-30-25 & & Alnus glutinosa & Gironde, France & FN561865 \\
\hline AldY SW13 & & Alnus glutinosa & Germany & KP238307 \\
\hline AldY SW23 & & Alnus glutinosa & Germany & KP238310 \\
\hline AldY A06-30-20 & & Alnus glutinosa & Gironde, France & FN561863 \\
\hline AldY SW4 & & Alnus glutinosa & Germany & KP238303 \\
\hline AldY SW8 & & Alnus glutinosa & Germany & KP238305 \\
\hline AldY SW17 & & Alnus glutinosa & Germany & KP238309 \\
\hline FD FG 1 & FD3 & Vitis vinifera & Serbia & KP238300 \\
\hline
\end{tabular}




\section{Supporting Information}

Table S2 Sequence identity of map gene of FDp and related strains identified in the present study and $16 \mathrm{SrV}$ phytoplasma strains available at 4 NCBI GenBank

\begin{tabular}{|c|c|c|c|c|c|c|c|c|c|c|c|c|c|c|c|c|c|c|c|c|c|c|c|c|c|c|c|}
\hline \# & Type & Strain & 1 & 2 & 3 & 4 & 5 & 6 & 7 & 8 & 9 & 10 & 11 & 12 & 13 & 14 & 15 & 16 & 17 & 18 & 19 & 20 & 21 & 22 & 23 & 24 & 25 \\
\hline 1 & FD1 & Vv128 & ID & & & & & & & & & & & & & & & & & & & & & & & & \\
\hline 2 & FD1 & Vv129 & 1 & ID & & & & & & & & & & & & & & & & & & & & & & & \\
\hline 3 & FD1 & $\mathrm{Ca} 249$ & 1 & 1 & ID & & & & & & & & & & & & & & & & & & & & & & \\
\hline 4 & FD1 & $\mathrm{Ca} 253$ & 1 & 1 & 1 & ID & & & & & & & & & & & & & & & & & & & & & \\
\hline 5 & FD1 & $\mathrm{Sa} 252$ & 0,998 & 0,998 & 0,998 & 0,998 & ID & & & & & & & & & & & & & & & & & & & & \\
\hline 6 & FD1 & Oi99 & 0,998 & 0,998 & 0,998 & 0,998 & 0,996 & ID & & & & & & & & & & & & & & & & & & & \\
\hline 7 & FD1 & Oi116 & 1 & 1 & 1 & 1 & 0,998 & 0,998 & ID & & & & & & & & & & & & & & & & & & \\
\hline 8 & FD1 & St121 & 1 & 1 & 1 & 1 & 0,998 & 0,998 & 1 & ID & & & & & & & & & & & & & & & & & \\
\hline 9 & FD1 & St142 & 1 & 1 & 1 & 1 & 0,998 & 0,998 & 1 & 1 & ID & & & & & & & & & & & & & & & & \\
\hline 10 & FD2 & Vv178 & 0,98 & 0,98 & 0,98 & 0,98 & 0,982 & 0,978 & 0,98 & 0,98 & 0,98 & ID & & & & & & & & & & & & & & & \\
\hline 11 & FD2 & Vv220 & 0,98 & 0,98 & 0,98 & 0,98 & 0,982 & 0,978 & 0,98 & 0,98 & 0,98 & 1 & ID & & & & & & & & & & & & & & \\
\hline 12 & FD2 & Ca158 & 0,98 & 0,98 & 0,98 & 0,98 & 0,982 & 0,978 & 0,98 & 0,98 & 0,98 & 1 & 1 & ID & & & & & & & & & & & & & \\
\hline 13 & FD2 & Oi12 & 0,98 & 0,98 & 0,98 & 0,98 & 0,982 & 0,978 & 0,98 & 0,98 & 0,98 & 1 & 1 & 1 & ID & & & & & & & & & & & & \\
\hline 14 & FD2 & Oi32 & 0,98 & 0,98 & 0,98 & 0,98 & 0,982 & 0,978 & 0,98 & 0,98 & 0,98 & 1 & 1 & 1 & 1 & ID & & & & & & & & & & & \\
\hline 15 & FD2 & $\mathrm{Td} 8$ & 0,98 & 0,98 & 0,98 & 0,98 & 0,982 & 0,978 & 0,98 & 0,98 & 0,98 & 1 & 1 & 1 & 1 & 1 & ID & & & & & & & & & & \\
\hline 16 & FD2 & $\mathrm{Td} 31$ & 0,98 & 0,98 & 0,98 & 0,98 & 0,982 & 0,978 & 0,98 & 0,98 & 0,98 & 1 & 1 & 1 & 1 & 1 & 1 & ID & & & & & & & & & \\
\hline 17 & FD3 & $\mathrm{Ca} 254$ & 0,984 & 0,984 & 0,984 & 0,984 & 0,985 & 0,982 & 0,984 & 0,984 & 0,984 & 0,982 & 0,982 & 0,982 & 0,982 & 0,982 & 0,982 & 0,982 & ID & & & & & & & & \\
\hline 18 & FD3 & $\mathrm{Ca} 257$ & 0,984 & 0,984 & 0,984 & 0,984 & 0,985 & 0,982 & 0,984 & 0,984 & 0,984 & 0,982 & 0,982 & 0,982 & 0,982 & 0,982 & 0,982 & 0,982 & 1 & ID & & & & & & & \\
\hline 19 & FD3 & $\mathrm{Ca} 256$ & 0,984 & 0,984 & 0,984 & 0,984 & 0,985 & 0,982 & 0,984 & 0,984 & 0,984 & 0,982 & 0,982 & 0,982 & 0,982 & 0,982 & 0,982 & 0,982 & 1 & 1 & ID & & & & & & \\
\hline 20 & FD3 & Oi102 & 0,982 & 0,982 & 0,982 & 0,982 & 0,984 & 0,98 & 0,982 & 0,982 & 0,982 & 0,98 & 0,98 & 0,98 & 0,98 & 0,98 & 0,98 & 0,98 & 0,998 & 0,998 & 0,998 & ID & & & & & \\
\hline 21 & FD3 & Oi115 & 0,984 & 0,984 & 0,984 & 0,984 & 0,985 & 0,982 & 0,984 & 0,984 & 0,984 & 0,982 & 0,982 & 0,982 & 0,982 & 0,982 & 0,982 & 0,982 & 1 & 1 & 1 & 0,998 & ID & & & & \\
\hline 22 & FD3 & Ho1 & 0,957 & 0,957 & 0,957 & 0,957 & 0,959 & 0,955 & 0,957 & 0,957 & 0,957 & 0,955 & 0,955 & 0,955 & 0,955 & 0,955 & 0,955 & 0,955 & 0,973 & 0,973 & 0,973 & 0,971 & 0,973 & ID & & & \\
\hline 23 & FD1 & FD70 & 1 & 1 & 1 & 1 & 0,998 & 0,998 & 1 & 1 & 1 & 0,98 & 0,98 & 0,98 & 0,98 & 0,98 & 0,98 & 0,98 & 0,984 & 0,984 & 0,984 & 0,982 & 0,984 & 0,957 & ID & & \\
\hline 24 & FD2 & V00-SP5 & 0,98 & 0,98 & 0,98 & 0,98 & 0,982 & 0,978 & 0,98 & 0,98 & 0,98 & 1 & 1 & 1 & 1 & 1 & 1 & 1 & 0,982 & 0,982 & 0,982 & 0,98 & 0,982 & 0,955 & 0,98 & ID & \\
\hline 25 & FD3 & VI04-Toscana1 & 0,984 & 0,984 & 0,984 & 0,984 & 0,985 & 0,982 & 0,984 & 0,984 & 0,984 & 0,982 & 0,982 & 0,982 & 0,982 & 0,982 & 0,982 & 0,982 & 0,996 & 0,996 & 0,996 & 0,994 & 0,996 & 0,969 & 0,984 & 0,982 & ID \\
\hline
\end{tabular}


Table 1 Insect vector specimens captured by yellow sticky traps in the test vineyard from May to November 2014, and FDp and related strains molecular identification and characterization in pooled insects

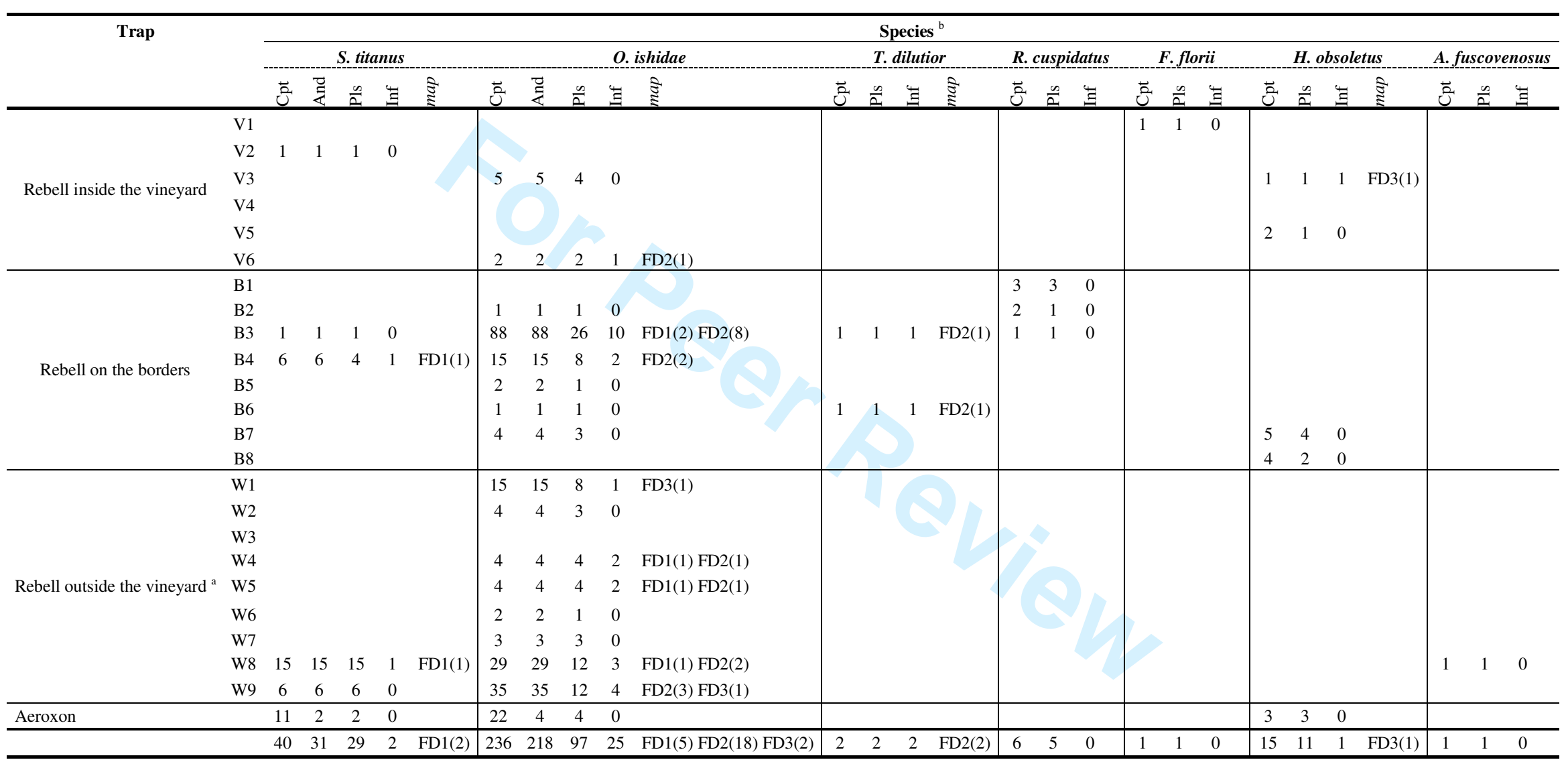

${ }^{a}$ traps W1 to W7 positioned at the external border of the forest neighboring other vineyards; traps W8 and W9 positioned within the forest

${ }^{\mathrm{b}} \mathrm{Cpt}$, captured specimens; And, analyzed specimens; Pls, pools; Inf, infected pools determined by real-time PCR; map, map-type determined by RFLP analysis of map gene amplified by nested PCR 
699 Table 2 Molecular identification and characterization of FDp and related strains in plants

700

\begin{tabular}{lcccccc}
\hline Host & No. of samples & Real-time PCR & map PCR & \multicolumn{3}{c}{ RFLP map types } \\
& & & & FD1 & FD2 & FD3 \\
\hline Vitis vinifera & 74 & 70 & 70 & 2 & 68 & 0 \\
Corylus avellana & 31 & 11 & 6 & 3 & 1 & 2 \\
Salix sp. & 10 & 3 & 1 & 1 & 0 & 0 \\
Clematis vitalba & 4 & 3 & 3 & 0 & 0 & 3 \\
\hline
\end{tabular}

701

702

703

704

705

706

707

708

709

710

711

712

713

714

715

716

717

718

719

720 
1

2

3

4

5

6

7

8

9

10

11

12

13

14

15

16

17

18

19

20

21

22

23

24

25

26

27

28

29

30

31

32

33

34

35

36

37

38

39

40

41

42

43

44

45

46

47

48

49

50

51

52

53

54

55

56

57

58

59

60

721 Table 3 GenBank accession numbers of map gene nucleotide sequences amplified from 722 representative FDp, FDp related and $16 \mathrm{SrV}$ phytoplasma strains identified in insects and plants 723

\begin{tabular}{|c|c|c|c|c|}
\hline RFLP map types & Host & No. of strains & Representative strain & Accession Number \\
\hline \multirow[t]{9}{*}{ FD1 } & Vitis vinifera & 2 & $\mathrm{Vv} 128^{\mathrm{a}}$ & KX245031 \\
\hline & & & $\mathrm{Vv} 129^{\mathrm{a}}$ & KX245030 \\
\hline & Corylus avellana & 3 & $\mathrm{Ca} 249^{\mathrm{b}}$ & KX245028 \\
\hline & & & $\mathrm{Ca} 253^{\mathrm{b}}$ & KX245033 \\
\hline & Salix sp. & 1 & $\mathrm{Sa} 252^{\mathrm{b}}$ & KX245029 \\
\hline & Orientus ishidae & 5 & Oi99 & KX245034 \\
\hline & & & Oi116 ${ }^{\mathrm{b}}$ & KX245032 \\
\hline & Scaphoideus titanus & 2 & $\mathrm{St} 121^{\mathrm{a}}$ & KX245035 \\
\hline & & & $\mathrm{St} 142^{\mathrm{a}}$ & KX245036 \\
\hline \multirow[t]{7}{*}{ FD2 } & Vitis vinifera & 68 & Vv178 ${ }^{a}$ & KX245026 \\
\hline & & & $\mathrm{Vv} 220^{\mathrm{a}}$ & KX245025 \\
\hline & Corylus avellana & 1 & $\mathrm{Ca} 158^{\mathrm{b}}$ & KX245023 \\
\hline & Orientus ishidae & 18 & $\mathrm{Oi} 12^{\mathrm{b}}$ & KX245021 \\
\hline & & & $\mathrm{Oi} 32^{\mathrm{b}}$ & KX245022 \\
\hline & Thamnotettix dilutior & 2 & $\mathrm{Td} 8^{\mathrm{b}}$ & KX245024 \\
\hline & & & $\operatorname{Td} 31^{\mathrm{b}}$ & KX245027 \\
\hline \multirow[t]{6}{*}{ FD3 } & Corylus avellana & 2 & $\mathrm{Ca} 254^{\mathrm{b}}$ & KX245038 \\
\hline & & & $\mathrm{Ca} 257^{\mathrm{b}}$ & KX245041 \\
\hline & Clematis vitalba & 1 & $\mathrm{Cv} 256^{\mathrm{b}}$ & KX245042 \\
\hline & Orientus ishidae & 2 & $\mathrm{Oi} 102^{\mathrm{b}}$ & KX245040 \\
\hline & & & Oil115 & KX245039 \\
\hline & Hyalesthes obsoletus & 1 & $\mathrm{Hol}^{\mathrm{c}}$ & KX245037 \\
\hline
\end{tabular}

724

${ }^{\mathrm{a}} \mathrm{FDp}$ strain; ${ }^{\mathrm{b}} \mathrm{FDp}$ related strain; ${ }^{\mathrm{c}} 16 \mathrm{SrV}$ phytoplasma strain

727

728

729

730

731

732

733

734

735 
736

737

738

739

740

741

742

743

744

745

746

747

748

749

750

751

752

753

754

755

756

757

758

759

760

\section{FIGURE LEGENDS}

Figure 1. View of the vineyard agro-ecosystem in Stabio, 'Canton Ticino' Region (Switzerland), and position of the yellow sticky traps (Rebell and Aeroxon) used to capture potential phytoplasma insect vectors. Rebell traps inside the vineyards: V1 to V6; Rebell traps on the borders: B1 to P8; Rebell outside the vineyard: W1 to W9. Fourteen aeroxon traps were positioned horizontally on the grapevine canopy inside the test vineyard.

Figure 2. Flight dynamics of Orientus ishidae (in blue) and Scaphoideus titanus (in red) in the vineyard in Stabio, 'Canton Ticino' Region (Switzerland), determined through the number of specimens captured inside the vineyard by Aeroxon (A) and Rebell (V1 to V6, B1 to B8) (B) traps, and outside the vineyard by Rebell (W1 to W9) traps (C).

Figure 3. Restriction fragment length polymorphism (RFLP) profiles obtained through double digestion with the enzymes AluI and Eco72I. RFLP patterns were visualized through electrophoresis in 3\% agarose gel. Attribution of RFLP profiles, identified in the present study, was carried out through the comparison with the profiles of the map-types FD1 (A), 2 (B), and 3 (C) (Arnaud et al., 2007). Acronyms of the FDp and related strains are reported in Table 3.

Figure 4. Unrooted phylogenetic tree inferred from analyses of nucleotide sequences of map gene. Minimum-Evolution method was carried out using the Jukes-Cantor model with the software MEGA6. The reliability of the analyses was subjected to a bootstrap test with 1000 replicates; bootstrap values lower than 50 are not shown. Phytoplasma strains and their nucleotide sequence accession numbers are reported in Table 3 and Table S1. Nucleotide sequences from the present work (Table 3) are written in bold characters. 
761

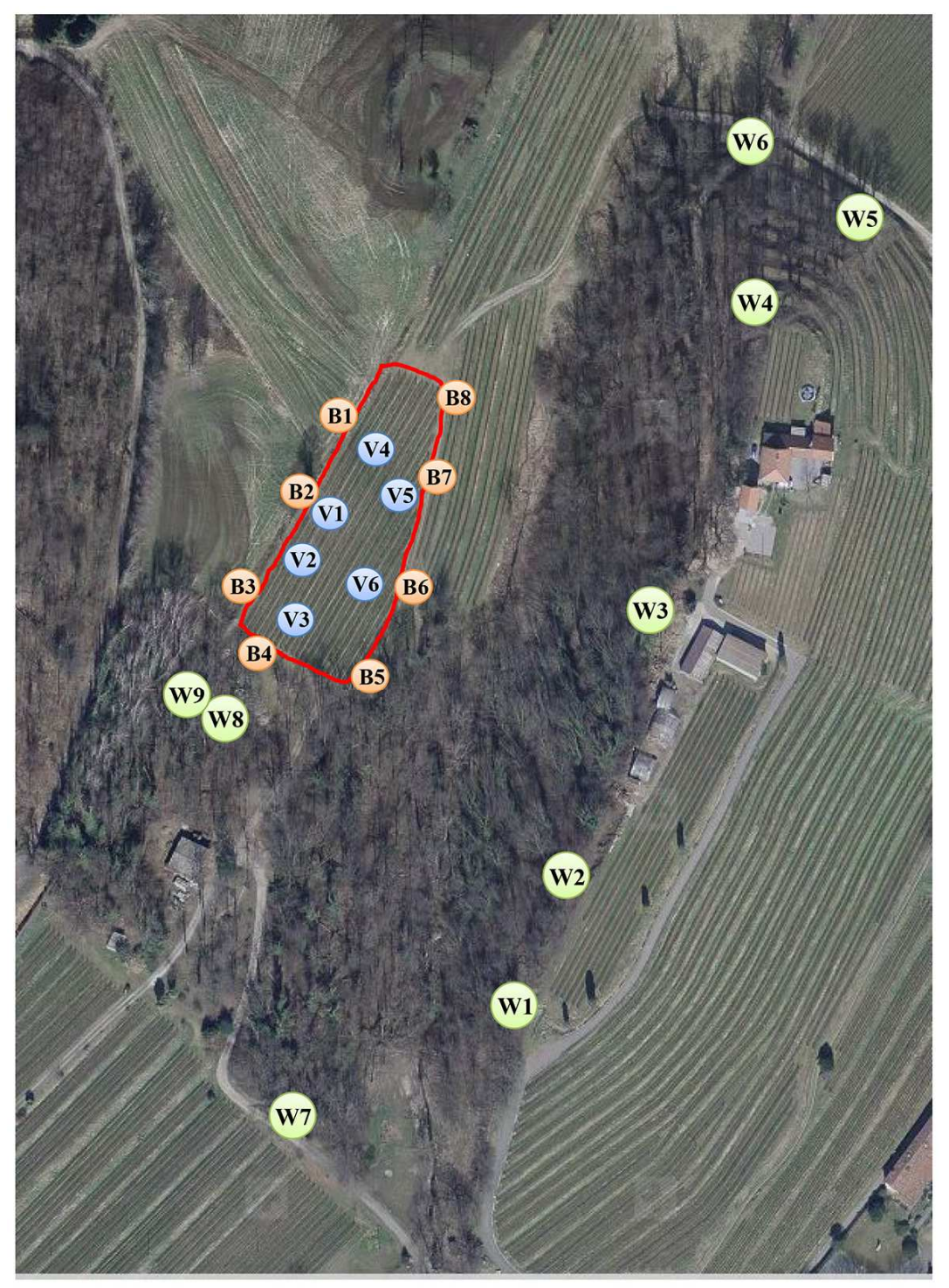

Figure 1 
771

772
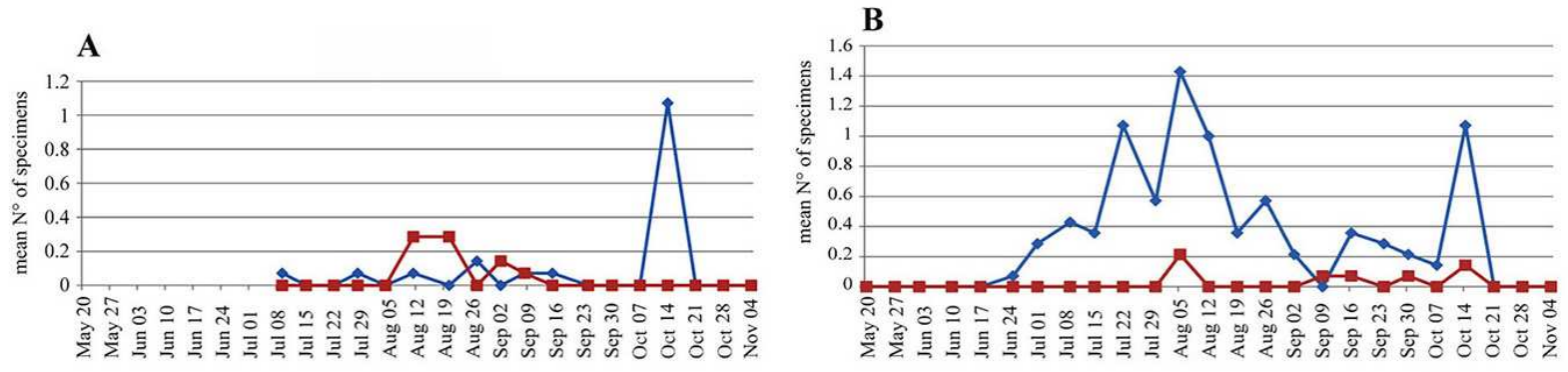

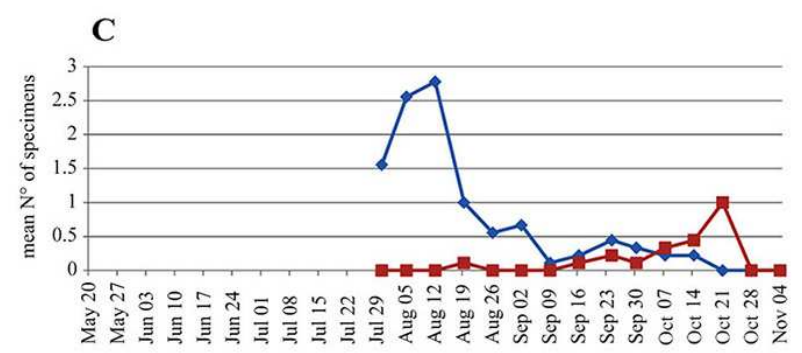

Figure 2

773
774
775
776
777
778
779
780
781
782
783
784
785
786
787
788
789
790 


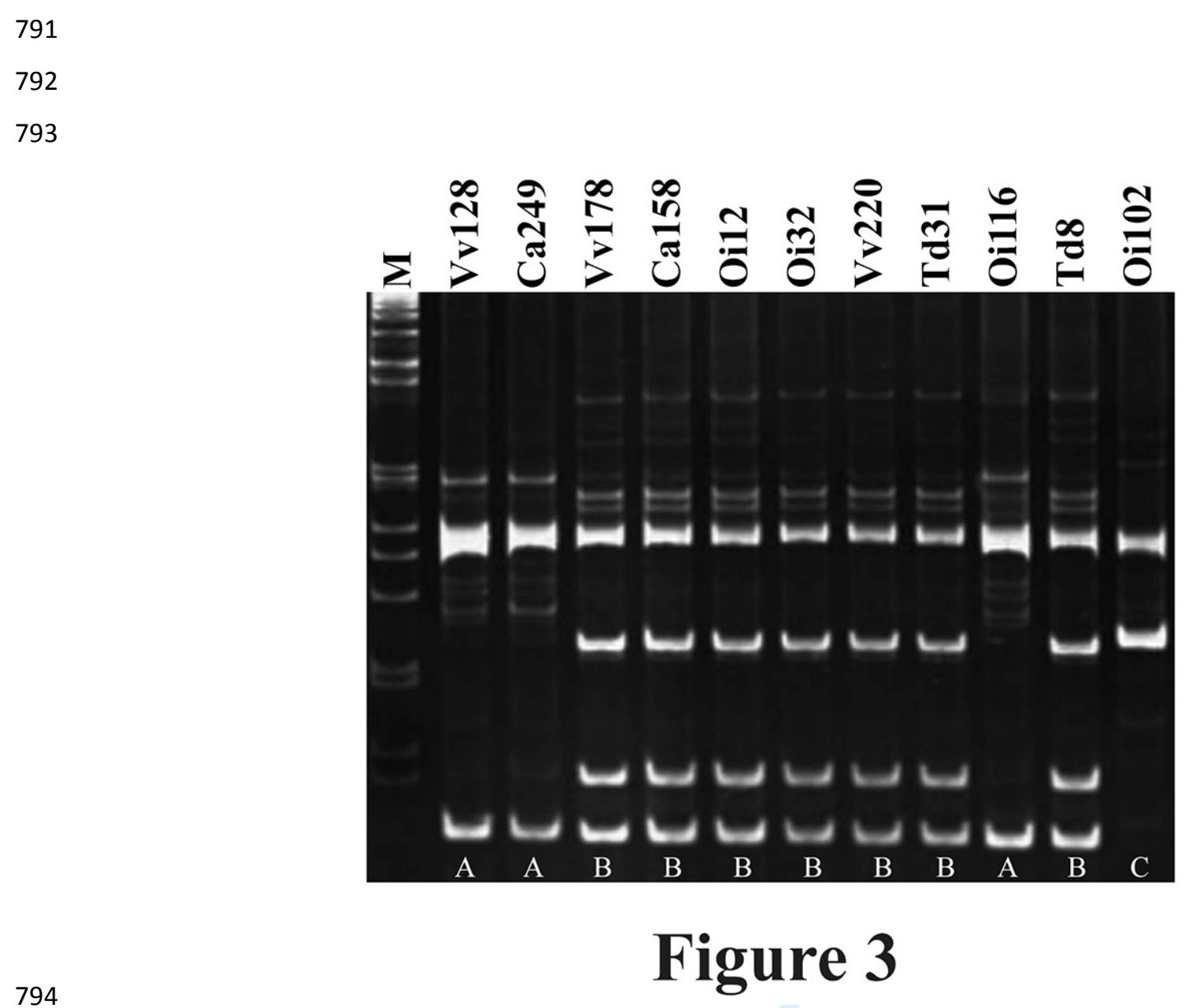

795

796

797

798

799

800

801

802

803

804

805

806

807

808

809 


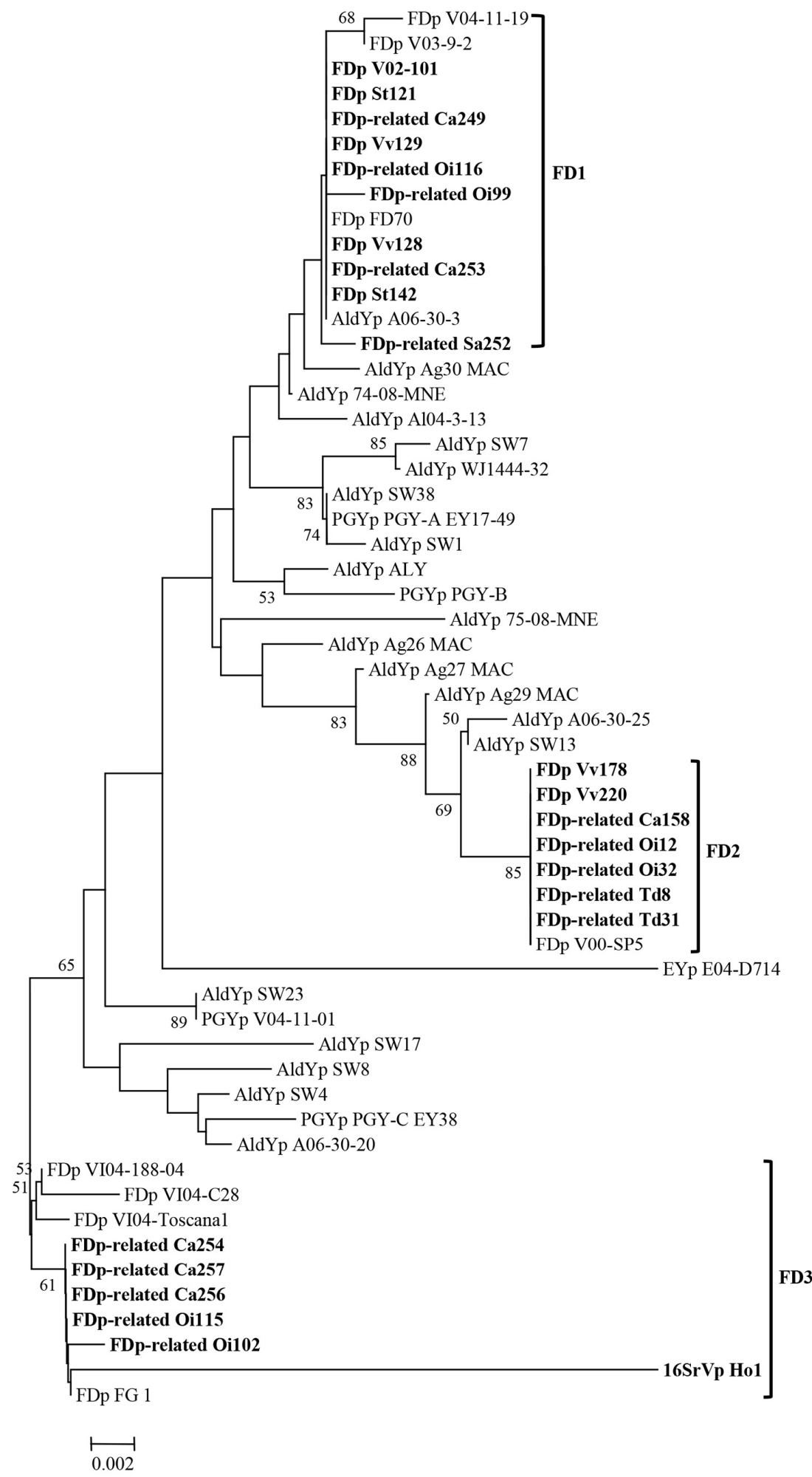

\section{Figure 4}

